\title{
Immunological tolerance induced by in utero injection
}

\author{
R D BARNES,* B E POTTINGER,* J MARSTON, $\dagger$ PAUL FLECKNELL,* \\ R H T WARD, $;$ SALTER, AND R L HEBERLING \\ From * the Clinical Research Centre, Harrow; $\nmid$ the Department of Anatomy, University of Birmingham; \\ $\ddagger$ the Department of Obstetrics, University College Hospital, London; and \$the South West Foundation for \\ Research and Education, Texas, USA.
}

SUMMARY Intrauterine injection of human whole blood into rabbit and rhesus monkey fetuses was found to result in long lasting unresponsiveness to human serum albumin. Intrauterine injection of viable allogeneic bone marrow cells into rabbit fetuses was without any apparent harmful effect and also resulted in permanent unresponsiveness demonstrated by donor red cell survival studies. The implication of these findings in respect of using this approach towards the correction of certain inherited diseases in man is discussed.

Induction of immunological tolerance is classically conferred by the very early injection of antigens. ${ }^{12}$ Especially significant in terms of the concept of tolerance were the experiments performed upon mice in the immediate neonatal period. ${ }^{34}$ Exposure to antigens earlier in life also leads to tolerance. For example, newborn animals are tolerant to transplacentally transmitted maternal immunoglobulin. ${ }^{5}$ However, there have been few recorded studies of induction of tolerance by intrauterine injection of the fetus, a study which we have performed here.

Our initial interest concerning tolerance centred upon early embryo aggregation derived mouse chimaeras. $^{6}{ }^{7}$ Derivation of such chimaeras is difficult and this led us to consider 'constructing' chimaeras by intrauterine injection. Motivation for this approach was the possibility of using this procedure to correct certain haemopoietic stem cell defects, for example, thalassaemia major. In this study we have attempted to ascertain whether unresponsiveness to intrauterine injected xenogeneic whole blood and allogeneic bone marrow can be achieved and whether unresponsiveness is permanent.

\section{Materials and methods}

\section{ANIMALS AND PRIMARY}

EXPERIMENTAL PROCEDURE

\section{Tolerance to xenogeneic whole blood}

Tolerance was investigated in a litter of NZW rabbits and one rhesus monkey (Macaca mulatta) which was available. Although the surgical techniques employed for the two species varied, the approach was essentially the same. Briefly, this Received for publication 18 June 1982. involved the injection of xenogeneic whole blood (human) into the peritoneal cavity of mid-late term rabbit and rhesus monkey fetuses and later challenging after birth.

Surgery in the rhesus monkey was performed as described by Cotes and her colleagues ${ }^{8}$ and involved hysterotomy, removal of amniotic fluid, and injection of whole human blood ( 2 to $4 \mathrm{ml}$ ip) through a 23 gauge needle into the fetus under direct vision. The incision was later repaired in layers. Before closure, amniotic fluid with $10 \mathrm{ml}$ of warm saline was introduced back into the amniotic cavity.

Laparotomy in the rabbit was followed by injection of human blood directly through the uterine wall into the peritoneal cavity of each fetus, using a 23 gauge needle, and the abdominal wall was repaired in layers as in the monkey. Thirteen fetuses were injected with $0.5 \mathrm{ml}$ group $A \mathrm{Rh}+$ ve human blood on the 28th day of a 31 day gestation. One monkey fetus was injected at 90 days with 2 to $4 \mathrm{ml}$ of $A \mathrm{Rh}+$ ve human whole blood.

\section{Tolerance to allogeneic bone marrow}

A second mid-term NZW rabbit was used here and viable allogeneic bone marrow cells from one adult NZW donor were injected into each of the seven fetuses as above. Each fetus was injected on the 26th day of a 31 day gestation with $6.4 \times 10^{6}$ viable femoral bone marrow cells suspended in $0.5 \mathrm{ml}$ RPMI $1640+$ pen/strep (100 units/ml).

\section{INVESTIGATION}

Rabbits and rhesus monkey injected with whole human blood

Of the 13 rabbit fetuses injected, 12 survived. The 
rhesus monkey was also injected and survived. All the animals appeared normal at birth and were reared by their mothers. Six of the injected rabbits together with six age matched untreated controls were first challenged at 12 weeks of age with $\simeq 20 \times 10^{10},{ }^{51} \mathrm{Cr}$-labelled red cells $(25 \mu \mathrm{Ci} / \mathrm{mg})$. This challenge was also carried out in the treated and control rhesus monkeys. Following the elimination of the ${ }^{51} \mathrm{Cr}$ radioactivity, all groups of animals were challenged with $1.0 \mathrm{mg}{ }^{125} \mathrm{I}-\mathrm{HSA}(25 \mu \mathrm{Ci} / \mathrm{mg})$ and this was repeated on four separate occasions when the radioactivity had been eliminated.

\section{Rabbits injected with allogeneic bone marrow}

Four rabbits survived injection of allogeneic bone marrow for testing, three having been cannibalised by the mother at birth. The survivors appeared normal and were successfully reared. Again these survivors were challenged at 12 weeks of age, together with three age matched untreated controls on three ozcasions with $\simeq 20 \times 10^{10},{ }^{51} \mathrm{Cr}$-labelled red cells $(25 \mu \mathrm{Ci} / \mathrm{mg})$.

In each case following the first challenge each animal was rechallenged once radioactivity could no longer be detected in any of the animals.

\section{Results}

\section{XENOGENEIC HUMAN BLOOD INJECTED}

ANIMALS

In both the rabbits and the rhesus monkeys there was a rapid and total loss (4 days) of ${ }^{51} \mathrm{Cr}$-radiolabelled red cells and there was no difference between the in utero injected animals and the untreated matched controls. This loss, one has to presume, resulted from interspecies human red cell lytic activity in both the rabbits and monkeys.

In respect of the results with labelled HSA both the rabbits and monkey presented very similar findings.

The results on the rabbits are detailed in table 1 and shown in diagram in fig 1 .

In contrast to the controls (fig 1) there was a generally delayed elimination of HSA in the in utero injected rabbits. Although there was some individual variation, this was to be expected. One possible explanation is that in utero injection of each individual fetus was not invariably successful. Alternatively, it is known that immunological response is variable. These limitations aside, the results confirm that relative unresponsiveness to HSA can be induced by in utero injection of whole blood. More recently we have demonstrated that this is also the case when pure HSA is injected alone (unpublished data), and again after five subsequent challenges unresponsiveness was maintained. In the controls there was evidence of an increasing rate of elimination of HSA in subsequent challenges compared with the primary challenge (table 1).

Permanent sustained tolerance to HSA was also?

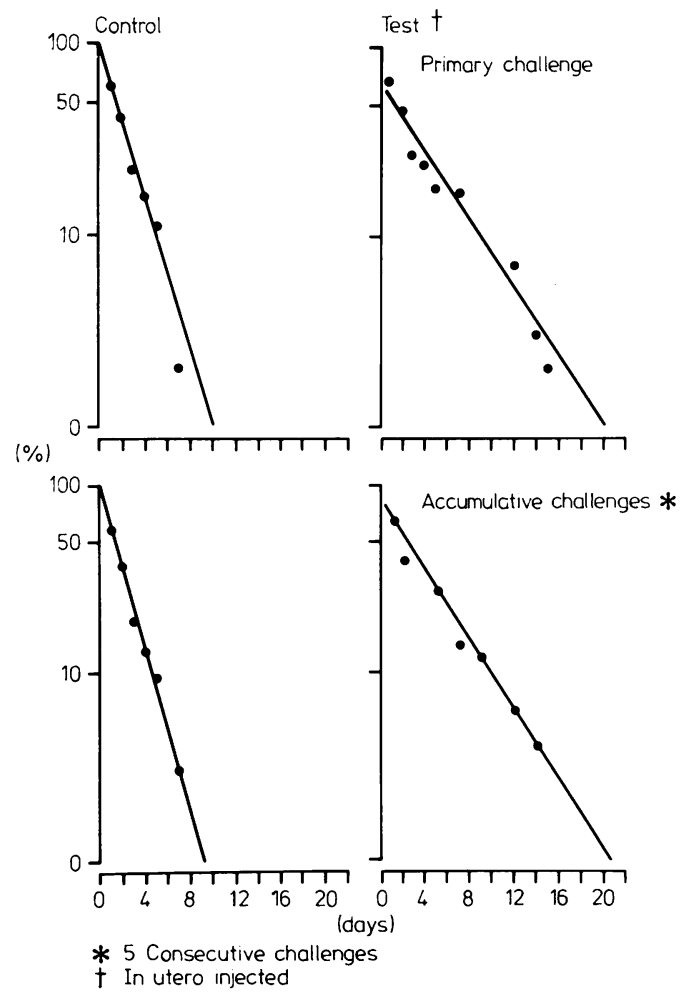

FIG 1 Elimination of ${ }^{125}$ I-labelled $H S A$ in six individual rabbits.

TABLE 1 Elimination of ${ }^{125}$ I-labelled HSA in normal and in utero injected rabbits.

\begin{tabular}{|c|c|c|}
\hline Challenge & $\begin{array}{l}\text { Controls } \\
\text { (6 animals) }\end{array}$ & $\begin{array}{l}\text { Tests* } \\
\text { (6 animals) }\end{array}$ \\
\hline $1 \mathrm{st}$ & $\begin{array}{l}50 \% \text { fall-off }(\text { days }) \\
\text { Range } 1 \cdot 40-2 \cdot 10 \\
\text { Median } 1 \cdot 88 \\
\text { Mean } 1 \cdot 80 \pm 0 \cdot 50 \\
100 \% \text { fall-off }(\text { days }) \\
\text { Range } 8 \cdot 0-10 \cdot 9 \\
\text { Median } 9 \cdot 80 \\
\text { Mean } 9 \cdot 7 \pm 2 \cdot 2\end{array}$ & $\begin{array}{l}50 \% \text { fall-off }(\text { days }) \\
\text { Range } 1 \cdot 80-2 \cdot 75 \\
\text { Median } 1 \cdot 90 \\
\text { Mean } 2 \cdot 00 \pm 0 \cdot 70 \\
100 \% \text { fall-off }(\text { days }) \\
\text { Range } 14 \cdot 0-22 \cdot 0 \\
\text { Median } 19 \cdot 5 \\
\text { Mean } 18 \cdot 8 \pm 6 \cdot 0\end{array}$ \\
\hline Subsequent $\dagger$ & $\begin{array}{l}50 \% \text { fall-off (days) } \\
\text { Range } 0 \cdot 60-1 \cdot 96 \\
\text { Median } 1 \cdot 60 \\
\text { Mean } 1 \cdot 40 \pm 1 \cdot 30 \\
100 \% \text { fall-off }(\text { days }) \\
\text { Range } 3 \cdot 10-10 \cdot 00 \\
\text { Median } 8 \cdot 90 \\
\text { Mean } 7 \cdot 20 \pm 6 \cdot 20\end{array}$ & $\begin{array}{l}50 \% \text { fall-off }(\text { days }) \\
\text { Range } 1 \cdot 82-2 \cdot 80 \\
\text { Median } 2 \cdot 00 \\
\text { Mean } 2 \cdot 10 \pm 0 \cdot 70 \\
100 \% \text { fall-off }(\text { days }) \\
\text { Range } 19 \cdot 0-22 \cdot 0 \\
\text { Median } 20 \cdot 2 \\
\text { Mean } 20 \cdot 3 \pm 2 \cdot 70\end{array}$ \\
\hline
\end{tabular}


seen in the sole in utero injected monkey which was tested. No apparent difference could be demonstrated between the in utero injected and control monkey following the 1st HSA challenge, but clear differences were seen in the $2 \mathrm{nd}, 3 \mathrm{rd}$, $4 \mathrm{th}$, and 5 th challenges. Although only performed in two animals the fact remains that the overall pattern (fig 2 ) is very similar to the rabbits (fig 1).

In both the test and control group of rabbits and monkeys a very rapid clearance of HSA was noted during the first 24 hours. This is assumed to be the result of elimination of denatured radiolabelled HSA. In contrast to the in utero injected unresponsive (tolerant) animals, the rapid elimination (post 24 hour) 'fall off' in the control animals is presumed to be the result of increasing sensitisation to HSA challenges. It might be argued that we only examined one in utero injected monkey (and one untreated control). However, the data are included here (1) to record the remarkable similarity with the situation in the rabbits and (2) to show that the phenomenon is not confined to the rabbit but also occurs in other species, species nearer to man, which
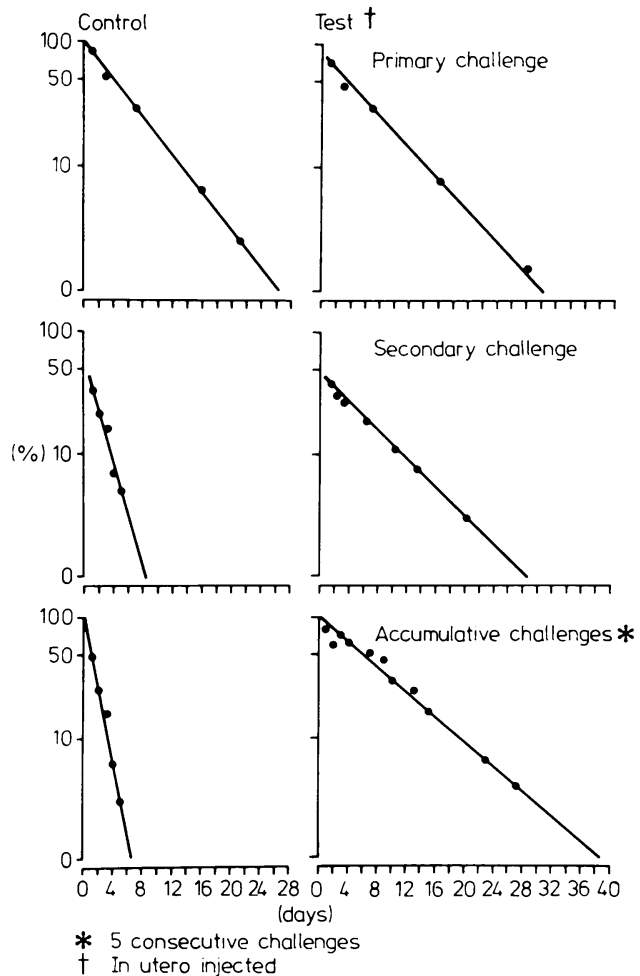

FIG 2 Elimination of ${ }^{125}$ I-labelled HSA in two rhesus monkeys, one in utero injected with $H S A$. is important in respect of our basic aim to consider the feasibility of the application of this approach to correct certain deficiency diseases in man.

RABBITS INJECTED WITH ALLOGENEIC BONE MARROW

When challenged with ${ }^{51} \mathrm{Cr}$-labelled donor red cells there were clear differences between the intrauterine injected animals and the untreated controls, as can be seen in table 2 , and more easily in fig 3 . Quite

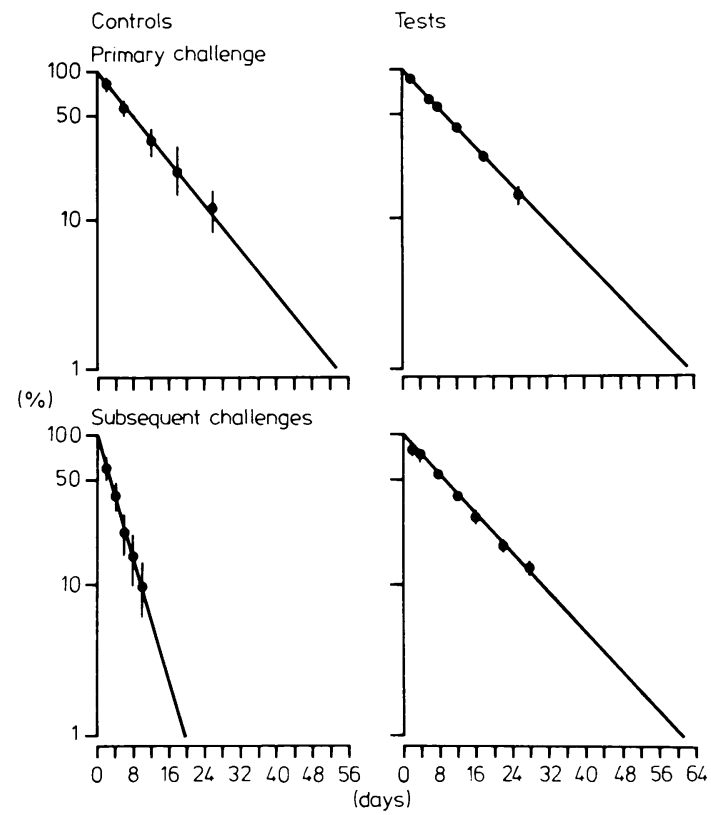

FIG 3 Elimination of ${ }^{51}$ Cr-labelled red cells grafted in utero with corresponding allogeneic bone marrow cells.

TABLE 2 Elimination of ${ }^{51} \mathrm{Cr}$-labelled allogeneic $R B C$ in in utero injected rabbits.

\begin{tabular}{|c|c|c|}
\hline Challenges & $\begin{array}{l}\text { Controls } \\
(3 \text { animals })\end{array}$ & $\begin{array}{l}\text { Tests* } \\
(4 \text { animals })\end{array}$ \\
\hline 1st & $\begin{array}{l}50 \% \text { fall-off }(\text { days }) \\
\text { Range } 7 \cdot 51-8 \cdot 42 \\
\text { Median } 8 \cdot 00 \\
\text { Mean } 7 \cdot 970 \pm 0 \cdot 450 \\
100 \% \text { fall-off }(\text { days }) \\
\text { Range } 48 \cdot 0-56 \cdot 34 \\
\text { Median } 53 \cdot 60 \\
\text { Mean } 52 \cdot 40 \pm 3 \cdot 94\end{array}$ & $\begin{array}{l}50 \% \text { fall-off }(\text { days }) \\
\text { Range } 9 \cdot 10-9 \cdot 60 \\
\text { Median } 9 \cdot 40 \\
\text { Mean } 9 \cdot 35 \pm 0 \cdot 250 \\
100 \% \text { fall-off }(\text { days }) \\
\text { Range } 61 \cdot 8-63 \cdot 0 \\
\text { Median } 62 \cdot 0 \\
\text { Mean } 62 \cdot 2 \pm 0 \cdot 5\end{array}$ \\
\hline Subsequent ${ }^{+}$ & $\begin{array}{l}50 \% \text { fall-off }(\text { days }) \\
\text { Range } 2 \cdot 20-3 \cdot 80 \\
\text { Median } 2 \cdot 60 \\
\text { Mean } 2 \cdot 90 \pm 0 \cdot 83 \\
100 \% \text { fall-off }(\text { days }) \\
\text { Range } 15 \cdot 6-23 \cdot 4 \\
\text { Median } 18 \cdot 0 \\
\text { Mean } 19 \cdot 0 \pm 3 \cdot 99\end{array}$ & $\begin{array}{l}50 \% \text { fall-off }(\text { days }) \\
\text { Range } 8 \cdot 00-8 \cdot 80 \\
\text { Median } 8 \cdot 30 \\
\text { Mean } 8 \cdot 35 \pm 0 \cdot 34 \\
100 \% \text { fall-off }(\text { days }) \\
\text { Range } 58-66 \cdot 2 \\
\text { Median } 60 \cdot 20 \\
\text { Mean } 63 \cdot 0 \cdot \pm 3 \cdot 73\end{array}$ \\
\hline
\end{tabular}

*In utero injected.

†Accumulated data of three challenges. 
clearly, the red cell survival was increased almost four-fold in the intrauterine grafted animals, and it must be assumed that the relative accelerated loss of labelled red cells in controls represents immune clearance. Tolerance to at least the donor red cell must be assumed to result from intrauterine bone marrow grafting.

\section{Discussion}

Fetal blood sampling is currently being employed in the diagnosis of various human blood diseases and perhaps the commonest is thalassaemia major. ${ }^{9}$ Our primary interest in tolerance to in utero grafts is the possibility of correction of such diseases by midgestational grafting of normal adult haematopoietic stem cells. Hopefully these cells will survive and, for example, in the case of thalassaemia major, proliferate and provide erythroid cells with normal haemoglobin. Even if the primary graft is not established, there is always the opportunity of a secondary graft in the postnatal period, since we anticipate having achieved tolerance. In this context it is of interest to note the findings of Rayfield and his colleagues. ${ }^{10}$ They showed that whereas lymphoid cells obtained from the human fetus before 18 weeks of in utero life were capable of reacting in an MLR, cytoxicity could not be demonstrated.

This is encouraging in respect to fetal grafting in humans at around 16 weeks' gestation, the time at which diagnosis of thalassaemia is usually performed. The implication is that the graft would be accepted and hopefully the child would be rendered tolerant. Here it would be an advantage to use the parents as stem cell graft donors. If secondary grafting was required this could be effected from either parent or from any unaffected sib. Of course there would be no question of this procedure being considered genetic engineering.

Although successful establishment of tolerance to the graft is anticipated to preclude or reduce the chance of rejection of bone marrow graft, there is always the problem of graft-versus-host (GVH) disease. Surprisingly, this does not appear to be a problem in the animals grafted in utero. Bangham et al, for example, showed that even $20 \times 10^{7}$ allogeneic bone marrow or spleen cells or both when injected into mid-gestational rhesus monkey fetuses failed to cause any apparent harmful GVH disease. ${ }^{11}$ We have obtained other evidence to support this. In both rabbits and baboons (Papio sp) (unpublished data) injection of allogeneic bone marrow cells fail to affect fetal development. The question that remains is if the graft is accepted why does graft-versus-host reactivity not occur? Although we have yet to establish evidence of chimaerism in the animals, results are encouraging and suggest the possibility of $\stackrel{\mathbb{\mathscr { C }}}{+}$ employing in utero grafting to correct certain $\Rightarrow$ haemopoietic stem cell defects and possibly other $\stackrel{\mathcal{F}}{+}$ inherited defects in man.

Here we have shown that permanent unresponsive- $\frac{\bar{\sigma}}{\bar{D}}$ ness to xenogeneic albumin can be induced in both $\frac{\bar{\rho}}{\widehat{\phi}}$ rabbits and rhesus monkeys by in utero injection of $\mathbb{\mathbb { }}$ mid-gestational fetuses, in the former even when retested one year after the final challenge described $\overrightarrow{0}$ here (unpublished data). In retrospect tolerance $\rightarrow$ might have been anticipated since there are many $\vec{\omega}$ cases where unresponsiveness to soluble antigens? can be induced by injection in the newborn. ${ }^{12-16}$ The same is true of rabbits born from mothers injected with HSA. ${ }^{17}$ In contrast, we have noted no change in. unresponsiveness in spite of five challenges over the $\vec{A}_{\vec{A}}$ course of one year and, as mentioned above, even $\overrightarrow{ }$ after a gap of an additional year. It may be argued오 that the repeated frequent challenges of the antigen in this situation may have contributed in some way $\mathbb{\Phi}$ to the permanency of tolerance. Alternatively, direct을 in utero injection of the antigen might be more efficient in inducing permanent tolerance. Perhaps of more importance, tolerance to allogeneic red cells can $\vec{\odot}$ be induced, apparently without any risk to the fetus. The relevance of this observation to the treatment of haemopoietic cell deficiencies in man is quite apparent.

\section{Addendum}

Since this study, additional investigation has been performed. Bone marrow cells were injected into fetuses solely in one horn of each of two mid-termo does. Results were essentially as above. No effect upon fetal development was noted in any of 11 liveo fetuses born from the two litters. The animals have all continued to remain alive and well. Moreover, half of the young were found to be tolerant to radio- $\delta$ labelled injected donor red cells on two consecutive 3 challenges. In contrast the remaining (control)음 animals showed increased red cell destruction, $>$ especially apparent on the second challenge.

The conclusion remains the same that tolerance can be induced to red cells, and probably also othero haemopoietic cells, by the in utero injection of 0 allogeneic bone marrow and, moreover, without any N harmful effect upon the fetus.

We are pleased to acknowledge the advice of ourळ colleagues, Drs Asherson, Billington, Denman,? Fisher, Modell, Webster, and Zanelli, and also Professor J Humphrey. We are also grateful for the enthusiastic encouragement of Professor Denys Fairweather who has supported this project. 


\section{References}

1 Billingham RD, Brent L, Medawar PB. Actively acquired tolerance of foreign cells. Nature $1953 ; 172$ :603-6.

2 Hasek M, Hraba T. Immunological effects of experimental embryonal parabiosis. Nature 1955;175:764-5.

${ }^{3}$ Billingham RD, Brent L. A simple method of inducing tolerance of skin homografts in mice. Transplant Bull $1957 ; 4: 67-71$.

4 Billingham RD, Brent L. Quantitative studies on tissue transplantation immunity. Philos Trans $R$ Soc Lond [Biol] 1959;242:439-77.

5 Dray S. Effect of maternal isoantibodies on the quantitative expression of two allelic genes controlling $\gamma$-globulin allotype specificities. Nature 1962;195:677-80.

6 Barnes RD. Tolerance in early embryo aggregation (EEA) derived mouse chimaeras. Transplant Proc 1976;8:359-62.

7 Barnes RD. The use of early embryo aggregation derived chimaeras. II. The study of disease processes. $J$ Immunogenet 1976;3:411-21.

8 Cotes PM, Hobbs KR, Bangham DR. Development of the immune response in the foetal newborn rhesus monkey. Immunology 1966;11:185-98.

9 Fairweather DVI, Ward RHT, Modell B. Obstetric aspects of midtrimester foetal blood sampling by needling or fetoscopy. Br J Obstet Gynaecol 1980;87:87-99.

10 Rayfield LS, Brent L, Rodeck CH. Development of cell-mediated lympholysis in human foetal blood lymphocytes. Clin Exp Immunol 1981;42:561-70.
11 Bangham DR, Cotes PM, Hobbs KR, Tee DEH. An attempt to determine the age at which "cellular immunological maturity" develops in the foetal rhesus monkey. A recorded discussion of the Proceedings by the Editorial Committee, Biology Institute TNO. Van Bekkum DW, ed. Rijswijk: Krips, 1962:187-92.

12 Hanan R, Oyama J. Inhibition of antibody formation in mature rabbits by contact with the antigen at an early age. $J$ Immunol 1954;73:49-53.

13 Cinader B, Dubert JM. Acquired immune tolerance to human albumin and the response to subsequent injections of diazo human albumin. Br J Exp Pathol 1955;36:515-29.

14 Cinader B, Dubert JM. Specific inhibition of response to purified protein antigens. Proc $R$ Soc Lond [Biol] 1956; 146:18-33.

15 Dixon FJ, Maurer PH. Fate of antibody following in-vivo combination with specific antigen. Proc Soc Exp Biol Med $1953 ; 84: 442-6$.

16 Dixon FJ, Maurer PH. Immunologic unresponsiveness induced by protein antigens. $J$ Exp Med $1955 ; 101: 245-57$.

17 Humphrey JH. Immunological unresponsiveness to protein antigens in rabbits. Immunology 1964;7:462-73.

Requests for reprints to Dr R D Barnes, Infant Development, Clinical Research Centre, Watford Road, Harrow, Middlesex HA1 3UJ. 